\title{
The challenges and opportunities of online learning during Covid-19 pandemic
}

\author{
Ho Nhut Quang ${ }^{1}$, Ha Minh Tri ${ }^{1 *}$ \\ ${ }^{1}$ International University, Vietnam National University Ho Chi Minh City, Vietnam \\ *Corresponding author: hmtri@hcmiu.edu.vn
}

\begin{tabular}{|c|c|}
\hline RTICLE INFO & ABSTRACT \\
\hline & \multirow{7}{*}{$\begin{array}{l}\text { As the Covid-19 pandemic continues to spread over a year } \\
\text { after the original outbreak, it is critical to have an open mind about } \\
\text { the innovations Higher Education Institutions (HEIs) have } \\
\text { implemented to keep teaching going, as they may help HEIs if } \\
\text { appropriately implemented. The pandemic has caused many } \\
\text { activities, including traditional educational activities, to be shut } \\
\text { down. This has necessitated a vast wave of response migration for } \\
\text { HEIs with Online Learning (OL) as the educational platform. This } \\
\text { paper conducts desk research to review the challenges and } \\
\text { opportunities of OL during Covid-19 pandemic. It was apparent } \\
\text { that OL is different from emergency remote teaching, and as a } \\
\text { result, OL is more justifiable. The unique aspects of the crisis } \\
\text { response migration strategies of HEIs, teachers, and learners were } \\
\text { discussed. Our findings offer insights for HEIs and especially } \\
\text { educational managers, teachers, and learners to be aware of such } \\
\text { challenges and opportunities to deal with them. }\end{array}$} \\
\hline & \\
\hline eceived & \\
\hline evised & \\
\hline cep & \\
\hline ywords: & \\
\hline & \\
\hline
\end{tabular}

\section{Introduction}

The Coronavirus Disease 2019 (COVID-19) outbreak is an infectious disease that is believed to have originated in Wuhan City in China around December 2019 and is currently affecting 222 countries and territories around the world (Worldometer, 2021). This virus continues to spread and is a serious threat for citizens, governments, and businesses worldwide.

On March 11, 2020, the World Health Organisation (WHO) classified the COVID-19 outbreak as a pandemic. In China, the spread of the disease is reported to have now declined due to serious preventive measures being taken (Gautam \& Hens, 2020). The WHO, however, documented 167,492,769 confirmed cases and 3,482,907 confirmed deaths worldwide as of May 27, 2021 (WHO, 2021). The virus's predominant characteristic is its long incubation period and swift spread (Qian et al., 2020). The Covid-19 pandemic has caused a tremendously negative impact on global economic well-being and quality of life, including the educational sector, during social distancing (Mofijur et al., 2021; Osman, 2020; Tran et al., 2020). Social distancing and other measures adopted by many countries caused lockdowns in many sectors, including transportation, tourism, production, sports, education and training, and entertainment (Bandyopadhyay, 2020).

By forcing all organizations to move to online channels, the Covid-19 pandemic has forced the physical closing of companies, sports events, and schools around the world. The Internet utilization and other critical technologies to produce educational materials, guidelines, and program management is known as Online Learning (OL) (Fry, 2001). According to 
Hrastinski (2008), there are two kinds of OL: synchronous and asynchronous, which can be heavily contrasted. Therefore, while teachers and educational institutions must understand the advantages and drawbacks of OL, it is critical that they understand its effectiveness and efficiency. This article focuses on the Crisis-Response Migration (CRM) methods of Higher Education Institutions (HEIs), learners, teachers who entered into OL, as well as the challenges and opportunities related to Covid-19 (Adedoyin \& Soykan, 2020). Additionally, it enriches the increasingly growing body of OL literature in the context of Covid-19 pandemic by offering thorough knowledge of the CRM methods of Instructional Delivery (ID) endorsed by HEIs, teachers, and learners.

\section{Literature review}

We have observed that Digital Transformation (DT) has been with us for some time now, and it is part of what we see in HEIs (Kopp, Gröblinger, \& Adams, 2019; Leszczynski et al., 2018). Institutions are grappling with transforming the digital world because they are concerned about the issue of applying digital tools across every domain of life, and many skills to use digital tools in all areas of life are incremental. Thus, colleges and universities are needed to ensure students have the ability to handle challenges or difficulties and provide appropriate remedies (Bond, Marín, Dolch, Bedenlier, \& Zawacki-Richter, 2018; Sandkuhl \& Lehmann, 2017). Specifically, HEIs are currently confronted with the problem of DT, as well as students' limited capabilities when it comes to using digital tools across all aspects of their lives (AbadSegura, González-Zamar, Infante-Moro, \& García, 2020). On the other hand, universities are expected to equip their students to deal with these challenges and offer potential remedies (Bond et al., 2018; Sandkuhl \& Lehmann, 2017). As a whole, DT regarding HEIs is considered the culmination of all digitalization processes needed to achieve a transformation process, providing HEIs with the advantages to efficiently pertain digital or online technologies (Kopp et al., 2019). The whole process, from proper strategic preparation to organizational trust to logical thinking in processes to joining and reinforcing all involved parties to individual, collaborative, and organizational knowledge, includes all of these elements (Cameron \& Green, 2020). These researchers said that online or digital learning is an innovative process gaining momentum as a replacement for conventional classroom interactions; they also noted that the new technology has emerged to foster spontaneous interaction between classmates and foster spontaneous interaction between teachers and students. Covid-19 created a DT of higher education, and because of this crisis, novel educational innovations, which are different from conventional management practices, are deployed in only a limited number of days (Strielkowski, 2020).

Kopp et al. (2019) set out to identify conditions related to the DT of HEIs and, according to them, these conditions are considered obstacles to the achievement of DT of institutions when compared to benefits that can be reaped and the assumptions relate to (1) technology, (2) competences, (3) pace, (4) change, and (5) financing. The use of the term "e-learning" to describe the changes in higher education institutions during DT is inaccurate. Online or digital learning is just among the numerous DT characteristics present in educational institutions. In addition to using such technological devices, tools, and the Internet, educational institutions are engaging in OL (Means, Toyama, Murphy, Bakia, \& Jones, 2009). It was suggested by TallentRunnels et al. (2006) that with increased access to technology and the Internet, students now have more motivation to pursue OL because, at the beginning of the millennium, innovation in technology and Internet accessibility has increased. However, Joshi et al. (2020) found that with the increase in technology and Internet accessibility, online or digital learning efficacy is questionable because learners and instructors are separated and have no opportunity to interact in 
person. The study by Hodges, Moore, Lockee, Trust, and Bond (2020) distinguished between well-thought OL experiences, and OL presented as a response to a crisis. To expand on this idea, the research group called the rise in remote learning in the face of this epidemic "emergency remote teaching." This term is in sharp contrast to the concepts of quality or effective OL.

Studies have proven that experienced teachers are capable of leading more effective online education by teaching and contributing to the development and advancement of other researchers' works by boosting several principles, prototypes, theories, ethics, and assessment practices around teaching, learning, and design of online course (Bozkurt \& Sharma, 2020; Hodges et al., 2020). One of the important causes of the increased migration during this pandemic is the subsequent lack of the advanced design and development process (Branch, Dousay, \& Walling, 2015). Because of this, online education has failed to work in the crisis as expected due to it being only about "emergency remote teaching" (Bozkurt \& Sharma, 2020; Hodges et al., 2020; Vlachopoulos, 2020).

\section{Methodology}

The research team conducted an online search to collect relevant publications for the terms "online learning," "Covid-19", "challenges," "opportunities" in keywords, titles, or abstracts that were published during 2019 - 2021 in journals specializing in online learning or distance education. These journals (including online magazine) include Asian Journal of Distance Education, The Internet and higher education, Educause review, EDUCAUSE quarterly, Interactive Learning Environments, Interactive Learning Environments, EdTech Magazine, The Journal of Academic Librarianship, Journal of Education for Teaching, American journal of pharmaceutical education, Review of educational research, Higher Learning Research Communications, Journal of Educational Technology \& Society. The searches returned 30 journal articles, reports, and book chapters. After screening the titles and abstracts, the team eliminated irrelevant publications and closely examined 13 publications for the review.

\section{CRM methods}

With the Covid-19 outbreak, it is apparent that the educational system is vulnerable to external threats (Bozkurt \& Sharma, 2020). Adedoyin and Soykan (2020) propose the CRM method, which outlines two types of responses to the crisis of the migration of moving online. These types of responses are called External-Integrated Migration (EIM) and External-Assisted Migration (EAM). The first pertains to how HEIs and teachers deliver the same instructions and assessments via video sessions, assignment submissions and forum discussions. The second refers to the external programs and software being used for instructional delivery, such as Moodle or Google Classroom. More specifically, EAM is defined as how HEIs utilize Web 2.0 platforms developed by third-party bodies (Adedoyin \& Soykan, 2020). EAM, where several educational organizations supply data on faculty staff and learners for migration and use these Web 2.0 platforms, like Moodle, etc., uses data from institutions to identify these people, and users can enter these platforms from websites. EIM pertains to a situation where HEIs incorporate Web 2.0 platforms developed externally by corporations into their OL platforms; such apps are BigBlueButton, Google Classroom, etc. (Adedoyin \& Soykan, 2020). Additionally, both EAM and EIM are all-inclusive when it comes to providing ID and assessment, both of which include the option of video conferencing, assignment submission, forum discussion, course evaluation, and the like. Schools have been forced to close due to the WHO's announcement regarding social distancing policy, which mandates the use of social distancing. As a result, students have been disrupted in their regular classes, which has necessitated the use of new teaching and learning methods that were not planned for. 
Several measures have been implemented to help curtail Covid-19 spread, including making every effort to maintain social distancing, and educational activities have been moved to remote educational platforms. As a result, this migration has introduced several logistical complications. One major problem associated with the migration: mandatory modification has been necessitated in academic managers, teachers, and learners' attitudes about the importance of OL (Ribeiro, 2020). Covid-19 pandemic only came about when distance education first became a widespread practice, and that played a role in helping these academic citadels (schools) as they migrated to safer locations. As a result of the announcement that all school facilities are being closed to combat the outbreak, there are only two alternatives for universities to implement. They are OL or receiving an alternate educational facility that they had on-site before the announcement. Thousands of universities throughout the world began DT as a means to get as close as possible to their objectives (Adedoyin \& Soykan, 2020). According to studies by Hodges et al. (2020) and Manfuso (2020), the pandemic leads to both CRM and smooth processes in some institutions. Within the context of crisis response migration methods, OL was introduced to provide greater leeway for teachers and learners while simultaneously limiting geographical and time constraints.

The students' and faculty members' capacity to identify and apply opportunities in response to crises, and their capacity to find information online about digital learning, may also be seen from their capability for information accessibility and Digital Competence (DC). Many faculty members and students are believed to be digital natives as those raised and brought up during the digital era are considered to be digital natives (Prensky, 2001). In light of this, it is expected that students will be technologically savvy. However, it is essential to note that the results obtained from Bennett, Maton, and Kervin's study (2008) indicated that a significant proportion of them do not have skill sets that are generally assumed of digital natives. Thus, it was concluded that the influence of brand-new advanced technologies has not yet been fully realized (Shariman, Razak, \& Noor, 2012). While HEIs in countries where digital emergency teaching has not yet been fully implemented are hampered by this final stage of technology (Digital Telecommunications), learners and faculty staff in developing countries who lack this technology face a little longer implementation times when using Web 2.0 platforms from their organizations.

\subsection{Challenges}

It is now evident that the educational system is susceptible to outside threats with the advent of the Covid-19 pandemic (Bozkurt \& Sharma, 2020). This significant shift in delivery methods, which included not only logistical issues but attitudinal changes, arrived with a number of logistical and attitudinal challenges (Ribeiro, 2020). The difficulties discussed here are associated with computer-based instructional operations during the period of the Covid-19 pandemic.

\subsubsection{Technology}

One factor that impacts learning is the capability of the teacher and the students to connect to the Internet (Hsiao, 2012; Pham \& Tran, 2019). Those with Internet connections that are too weak to complete assignments may be denied access to OL. To the extent that learning must be based on technological tools and the supply of those tools is a struggle for educational institutions, faculty, and students, this problem has become even more pronounced. Once the student tried to download the browser multiple times and it was revealed that she was utilizing an obsolete device incompatible with the web browser, she could not download the browser (Wijekumar, Ferguson, \& Wagoner, 2006). 


\subsubsection{Socio-economic factor}

Students at schools who are relatively disadvantaged economically have used computers and free-of-charge Internet to help them (Demirbilek, 2014). Because of the school shutdown, the process of this group of learners' migration is assumed to be drawn out. To a great extent, indeed, students from socioeconomically disadvantaged backgrounds will almost certainly discover it not easy to migrate sooner than expected because they may not get to school because of the outbreak. The findings of Fishbane and Tomer (2020) revealed that learners without Internet access could be left to deal with the Covid-19 outbreak on their own, indicating that when poverty incidence rises, the availability of Internet connections quickly declines. Further implications can be drawn from this because students who are not or cannot afford broadband connections have the greatest need and are therefore at the greatest risk of separation from their learning environment when an outbreak occurs in the community.

\subsubsection{Digital Competence (DC)}

To gain an advantage while using digital devices, we should understand all the skills and knowledge they require. These include problem-solving, cooperation, and management of information, to achieve a positive outcome while also prioritizing effectiveness and ethics (Ferrari, 2012). Although some millennials see only schooling as their future, others expect to be both educationally and digitally competent across all aspects of life in this current industrial era (Bennett et al., 2008). Learners and teachers deficient in DT will most likely have trouble keeping up with the latest technologies. The information is purportedly provided by AlkaPwnige (2020) and is found in a video file uploaded to the platform. In the video, people, apparently unaware that they are going to use the platform in this manner, regularly go nude and sometimes dress up in the comfort station. According to current research, the use of digital devices (in this case, the platform) is causing users to unconsciously employ the service (causing this pattern of usage to occur). Avoiding digital device use can help mitigate this problem. Libraries are projected to follow the current efficiency trend, as libraries have greater DT during this epidemic than they had previously, in that students, faculty, and other stakeholders can rely on efficiently effective services delivered digitally via the library's digital library, learners and teachers with low DT will encounter issues when trying to utilize the digital library efficiently. The use of data on a parameter with a favorable association and a considerable impact on applying computerized libraries. Omotayo and Haliru (2020) have concluded that DT is a parameter with a favorable association and a significant impact on learners.

\subsubsection{Assessment and supervision}

After ID, evaluation should occur where teachers may utilize various assessment techniques to examine learning activities to determine if their goals have been met with tests, quizzes, and examinations to make sure their learning goals have been met. While we are well aware of all the documentation on measurement theory and tests, we do not have information on the steps required to develop and choose test items written by instructors. As a result, it is common for OL to include tests that students can only complete alone. This prevents instructors from closely supervising learners and, as a result, makes it unlikely to police and control deceiving (Arkorful \& Abaidoo, 2015; Pham \& Tran, 2019). While Osterlind (2005) believes that ICT-enhanced testing formats, including performance-based formats, constructed-response, sentence-completion or short-answer, true-false, and matching, several students are trying out different test formats to see which one is most appropriate for e-learning.

\subsubsection{Heavy workload}

In addition to the sheer volume of tasks that universities face during this DT process, many ICT units within institutions are called upon to create electronic platforms integrate current 
apps externally into their structures and go through full migration of all internal applications to external applications. Teachers also convey some of the work volumes as they are accountable for preparing their course materials for use on electronic platforms that will be highly challenging and take a heavy toll on both your financial and personal resources (Akkoyunlu \& Soylu, 2006). OL is recognized to offer more time to be dedicated to better levels of learning in the classrooms. It is, however, at the cost of workload (Phillips, Schumacher, \& Arif, 2016). This includes the time for creating online lectures, preparing quizzes and assignments. This, in turn, may lead to mental health issues (Adedoyin \& Soykan, 2020).

\subsubsection{Compatibility}

OL is an excellent complement to social science and humanities studies, which were demonstrated effective by researchers. In contrast, researchers have contested the capacity of OL to partner with other disciplines like medical and sports sciences, where the application of handson experiences is necessary to effective learning (Leszczynski et al., 2018). The method for obtaining this goal relies on remote laboratories utilized in OL and virtual laboratories provided by OL, the distance between theory and practice (Iqbal et al., 2015). With the ubiquity of OL, it can be applied in various disciplines, but, at the moment, it is not able to be effectively and efficiently employed, and the large open gap remains unfilled at this time (Leszczynski et al., 2018). As a result, medical students are currently forbidden from doing any patient-facing activities by March 2020, as was stated by the Association of American Medical Colleges (AAMC) in their recommendations. Still, the school of Brown University is assisting trainees by shifting some of the training coursework to online platforms. Although they are required to go back to the wards to perform direct patient interaction work while the Covid-19 suspension is lifted, those students will not be allowed to return to class until the suspension is over. This means that face-to-face training is incompatible with OL, as they cannot be used in conjunction, but that OL can merely be utilized to supplement the in-person training method until a return to the traditional training setting is possible (Leszczynski et al., 2018). In their research, Boczkowska, Bakalarski, Sviatoslav, and Leszczyński (2018) suggested that e-learning initiatives are necessary for the continual education of healthcare providers and to add a value of learning in nursing care. They also recommended extra steps to advance OL programs.

\subsection{Opportunities}

The various advantages associated with OL, including portability (Pham \& Tran, 2019; Smedley, 2010), availability of interaction (Leszczynski et al., 2018; Wagner, Hassanein, \& Head, 2008), self-paced learning (Bates \& Bates, 2005; Pham \& Tran, 2019), and numerous other resources, are the primary factors in the rise in its adoption at universities today, which are motivated by a desire to align their activities with practices (both local and global) and policies in order to help limit Covid-19 spread and retain the academic calendar. Public and private universities and other HEIs have countered the outbreak with the quick DT of their educational events. This is to be considered apart from the primary functions of universities: education and economy. Although they discuss the social roles of universities, Wang and Zha (2018) point out how significant the global pandemic effort could be, which will be handled by universities and educational and economic institutions around the world. According to Manfuso (2020), educators now have a clear roadmap that they can use to engage large stakeholders in education to begin the process of developing a new market for ID. If the pandemic continues for an extended time, it will only be more common for OL to become the predominant manner of learning and teaching. 


\subsubsection{Research innovations}

Poon and Peiris (2020) believe that the global spread and intensity of the deadly virus call for emergency measures to be taken by WHO, considering the unprecedented emergency WHO declared in the wake of the swift and spread of the virus worldwide. As investigators rapidly work to find short- and long-term remedies to the threat posed on humanity by the virus, instructional technologists - especially distance education investigators - are required to leverage this unexpected rise in OL participants to bring forth novel advancements for research. Several major research developments must be addressed as a result of this advancement: (a) to meet the evolving needs of OL, it is necessary to create new models that can accommodate the rapid change; (b) to evaluate the process of DT, it is necessary to investigate the methods by which institutions have migrated to the digital realm; (c) design more expandable and person-specific OL models; (d) design learning models that reduce the workload on instructors; (e) revamp the learning process. Thus, they will be devoting additional research time to conduct additional research activities due to the presence of a widespread issue and considerable research publications and advancements.

\subsubsection{Technological innovations}

Due to the vast array of institutions involved in providing researchers with areas for collaboration, institutions have taken on the task of accommodating avenues to bring about favorable results for the pre-emptive and curative measures for the pandemic. Because of these duties and for a short period, some HEIs in North Cyprus have created research innovations to help health workers and the general public stop the outbreak's spread. These additional technologies encompass the new "Medical Shields" (Eastern Mediterranean University, 2020) and "3D Multiplexer Ventilator" (Near East University, 2020). Wider opportunity to incorporate modern innovation arose from advancements in the 1960s and 1970s that brought on the microchip and the digital computer. Beech (2020) referred to this as "an opportunity that brings rocket technology and digital computers to the world." According to him, a number of the immediate technological advancements produced by this time include 3D Printed Hands-Free Door Openers, Basic Ventilators, Spiderman Wrist-Mounted Disinfectant Sprays, and a bracelet that makes a noise whenever someone tries to pat their face. The industry must respond in the event of another crisis like this because, with a resurgent Covid-19 outbreak, it is evident that IT pros will be able to execute another strategic deployment. Thus, this can be adopted as part of an ongoing business strategies and crisis management strategies.

\section{Discussion and conclusion}

To see how important instructional technology has been to education in helping to ease the effects of this global pandemic, one only needs to look at the prominence of ID and design and evaluation platforms as the only platforms for instructional design and delivery and assessment. Researchers worldwide and across all disciplines are working towards discovering preventive's goals and curative methods for the Covid-19. Therefore, modern research findings must be shared. Information flows are created to apply collaborative inquiry and technological networking to the certainty of feasible Covid-19 research (Wang, Cheng, Yue, \& McAleer, 2020). The emergence of online education has an innate connection to careful planning and the designs of instructional materials. Still, the introduction of universities to online education is in question because of the lack of a proper plan, design, and development of online instructional programs due to the overwhelming and explosive rise.

Migration and crisis response measures adopted by universities have been found to only 
account for delivery media, with no regard for effective online education theories and models. The world has fallen victim to a global pandemic, and so CRM should not be equated with effective OL or DT of universities. Instead, this should be seen from the unique type of remote teaching platforms known as emergency teaching platforms. According to Ala-Mutka, Punie, and Redecker (2008), DC should be viewed as an emergency remote teaching problem. Therefore, HEIs should not need to design a separate platform for learning digital skills. Instead, these skills should be incorporated into all subjects' teaching and learning processes. Omotayo and Haliru (2020) provided further details by arguing that learners need to be motivated to acquire DC to maintain relevance in modernity. Researchers who specialize in educational technology must direct their research to establish different evaluation approaches free of academic dishonesty, with careful consideration of the guidelines to achieve objective and impartial evaluation systems (Bozkurt \& Sharma, 2020). As in previous instances, the requirement for learning with Internet technologies depends on technology and Internet access. HEIs can cooperate with the telecommunication sector to either offset the Internet subscription cost or offer free-of-charge Internet data to learners and teachers as part of their CSR (Corporate Social Responsibilities). When it comes to the education field, research activities should be geared toward developing a universal OL model that can apply to all fields of study to fix the compatibility problem of cross-disciplinarity.

The prevalence and use of OL (sometimes referred to as remote teaching), such as during an emergency, will inevitably lead to students and faculty developing comfort with and proficiency with using tools and technology in their teaching and learning. This kind of familiarity, plus work environments where technology is more widely used, will most likely be beyond the school and onto the job setting. Han and Ellis (2019) posited that faculty must help learners identify and define the core values of blended learning through discussions and, additionally, demonstrate the benefits of traditional face-to-face learning and online discussion. Furthermore, to obtain better quality results, technical solutions implemented to increase the level of remote emergency teaching need to implement methods to assess test items accurately and conduct field trials, as expressed by Osterlind (2005). Despite HEIs and other citadels of learning having shifted their delivery platforms to online platforms in a sudden and surprising manner, it is evident that OL will continue to grow, and education will turn more toward a blend of online and traditional education. To better understand the nature of the challenges these students and faculty were facing, it is recommended that a new type of emergency teaching evaluation instrument be developed to gather additional insightful information about the crisisresponse migration methods and the related problems these students and faculty were facing.

\section{Limitations and future research directions}

This research also suffers several limitations. First, our research only focuses on challenges and opportunities of online learning during Covid-19 pandemic, and searches were conducted in specialized journals on education which are not exhaustive. Therefore, it may not provide a comprehensive overview of the challenges and opportunities of online learning over time. Future research may want to explore other journals more in-depth to gain a better insight into the challenges and opportunities of online learning. Second, our analysis provides an overview of the challenges and opportunities of online learning during Covid-19 pandemic in general. Future research may want to study a specific country in-depth, such as Vietnam, to have a more concrete picture of the challenges and opportunities of online learning during the Covid19 pandemic in Vietnam. 


\section{References}

Abad-Segura, E., González-Zamar, M. D., Infante-Moro, J. C., \& García, G. R. (2020). Sustainable management of digital transformation in higher education: Global research trends. Sustainability, 12(5), Article 2107. doi:10.3390/su12052107

Adedoyin, O. B., \& Soykan, E. (2020). Covid-19 pandemic and online learning: The challenges and opportunities. Interactive Learning Environments, 1-13. doi:10.1080/10494820.2020.1813180

Akkoyunlu, B., \& Soylu, M. Y. (2006). A study on students' views on blended learning environment. Turkish Online Journal of Distance Education, 7(3), 43-56.

Ala-Mutka, K., Punie, Y., \& Redecker, C. (2008). Digital competence for lifelong learning. Institute for Prospective Technological Studies (IPTS), European Commission, Joint Research Centre. Technical Note: JRC, 48708, 271-282.

AlkaPwnige (2020). Zoom funny moments and fails - Online school trolling - Funny clips compilation. Retrieved April 10, 2021, from https://www.youtube.com/watch?v= Wt1ER8Q7YaQ\&ab_channel=AlkaPwnige

Arkorful, V., \& Abaidoo, N. (2015). The role of e-learning, advantages and disadvantages of its adoption in higher education. International Journal of Instructional Technology and Distance Learning, 12(1), 29-42.

Bandyopadhyay, S. (2020). Coronavirus disease 2019 (Covid-19): We shall overcome. Clean Technologies and Environmental Policy, 22(3), 545-546. doi:10.1007/s10098-020-01843-w

Bates, A. W., \& Bates, T. (2005). Technology, e-learning and distance education. London, UK: Routledge Psychology Press.

Beech, P. (2020). These new gadgets were designed to fight Covid-19. Retrieved April 10, 2021, from https://www.weforum.org/agenda/2020/04/coronavirus-covid19-pandemic-gadgetsinnovation-technology/

Bennett, S., Maton, K., \& Kervin, L. (2008). The 'digital natives' debate: A critical review of the evidence. British Journal of Educational Technology, 39(5), 775-786. doi:10.1111/j.14678535.2007.00793.x

Boczkowska, K., Bakalarski, P., Sviatoslav, M., \& Leszczyński, P. (2018). The importance of elearning in professional improvement of emergency nurses. Critical Care Innovations, 1(1), $16-24$.

Bond, M., Marín, V. I., Dolch, C., Bedenlier, S., \& Zawacki-Richter, O. (2018). Digital transformation in German higher education: Student and teacher perceptions and usage of digital media. International Journal of Educational Technology in Higher Education, 15(1), 48. doi:10.1186/s41239-018-0130-1

Bozkurt, A., \& Sharma, R. C. (2020). Emergency remote teaching in a time of global crisis due to CoronaVirus pandemic. Asian Journal of Distance Education, 15(1), i-vi.

Branch, R. M., Dousay, T. A., \& Walling, D. R. (2015). Survey of instructional development models. Bloomington, Indiana: Association for Educational Communications and Technology.

Cameron, E., \& Green, M. (2020). Making sense of change management: A complete guide to the models, tools and techniques of organizational change. New York, NY: Kogan Page. 
Demirbilek, M. (2014). The 'digital natives' debate: An investigation of the digital propensities of university students. Eurasia Journal of Mathematics, Science and Technology Education, 10(2), 115-123.

Eastern Mediterranean University. (2020). Visual arts and communication design department: Emu visual arts and communication design department's contribution to health workers. Retrieved April 10, 2021, from https://www.emu.edu.tr/en/news/news/emu-visual-arts-andcommunication-design-departments-contribution-to-healthworkers/1206/pid/3393

Ferrari, A. (2012). Digital competence in practice: An analysis of frameworks (JRC technical report). Retrieved April 12, 2021, from https://ifap.ru/library/book522.pdf

Fishbane, L., \& Tomer, A. (2020). As classes move online during Covid-19, what are disconnected students to do? Retrieved April 10, 2021, from Brookings website: https://www.brookings.edu/blog/ the-avenue/2020/03/20/as-classes-move-online-duringcovid-19-what-are-disconnected-students-to-do/

Fry, K. (2001). E-learning markets and providers: Some issues and prospects. Education and Training, 43(4/5), 233-239. doi:10.1108/EUM0000000005484

Gautam, S., \& Hens, L. (2020). SARS-CoV-2 pandemic in India: What might we expect? Environment, Development and Sustainability, 22(5), 3867-3869. doi:10.1007/s10668-02000739-5

Han, F., \& Ellis, R. A. (2019). Identifying consistent patterns of quality learning discussions in blended learning. The internet and higher education, 40, 12-19. doi:10.1016/j.iheduc.2018.09.002

Hodges, C., Moore, S., Lockee, B., Trust, T., \& Bond, A. (2020). The difference between emergency remote teaching and online learning. Educause Review, 27, 1-12. doi:10.1080/10494820.2020.1725896

Hrastinski, S. (2008). Asynchronous and synchronous e-learning: A study of asynchronous and synchronous e-learning methods discovered that each supports different purposes. EDUCAUSE Quarterly: EQ., 31(4), 51-55.

Hsiao, E. L. (2012). Synchronous and asynchronous communication in an online environment: Faculty experiences and perceptions. Quarterly Review of Distance Education, 13(1), 15-30.

Iqbal, S., Zang, X., Zhu, Y., Hussain, D., Zhao, J., Gulzar, M. M., \& Rasheed, S. (2015, November 13-15). Towards MOOCs and their role in engineering education. Paper presented at the 2015 7th International Conference on Information Technology in Medicine and Education (ITME), Huangshan, Anhui, China. doi:10.1109/ITME.2015.89

Joshi, O., Chapagain, B., Murray, B. D., Kharel, G., Poudyal, N. C., \& Mehmood, S. R. (2020). Benefits and challenges of online instruction in agriculture and natural resource education. Interactive Learning Environments, 1-12. doi:10.1080/10494820.2020.1725896

Kopp, M., Gröblinger, O., \& Adams, S. (2019). Five common assumptions that prevent digital transformation at Higher Education Institutions. INTED2019 Proceedings, 1448-1457. Retrieved April 10, 2021, from https://library.iated.org/publication_series/INTED

Leszczynski, P., Charuta, A., Laziuk, B., Galazkowski, R., Wejnarski, A., Roszak, M., \& Kolodziejczak, B. (2018). Multimedia and interactivity in distance learning of resuscitation guidelines: A randomised controlled trial. Interactive Learning Environments Interactive Learning Environments, 26(2), 151-162. 
Manfuso, L. (2020). How the remote learning pivot could shape higher Ed IT. Retrieved May 10, 2021, from https://edtechmagazine.com/higher/article/2020/04/how-remote-learningpivot-could-shape-higher-ed-it

Means, B., Toyama, Y., Murphy, R., Bakia, M., \& Jones, K. (2009). Evaluation of evidencebased practices in online learning: A meta-analysis and review of online learning studies. Retrieved April 4, 2021, from U.S. Department of Education website: https://search.usa.gov/search?utf8=\%E2\%9C\%93\&affiliate=ed.gov\&query=Evaluation + of + Evidence-Based+Practices+in+Online+Learning\%3A+A+Meta-

Analysis+and+Review+of+Online+Learning+Studies

Mofijur, M., Fattah, I. M. R., Alam, M. A., Islam, A. B. M. S., Ong, H. C., Rahman, S. M. A., ... Mahlia, T. M. I. (2021). Impact of Covid-19 on the social, economic, environmental and energy domains: Lessons learnt from a global pandemic. Sustainable Production and Consumption, 26, 343-359. doi:10.1016/j.spc.2020.10.016

Near East University. (2020). Near East University medical engineer: Near East University engineers produced alternative support breathing apparatus. Retrieved April 10, 2021, from https://neu.edu.tr/near-east-university-engineers-produced-alternativesupportbreathing-apparatus/?lang=en

Omotayo, F. O., \& Haliru, A. (2020). Perception of task-technology fit of digital library among undergraduates in selected universities in Nigeria. The Journal of Academic Librarianship, 46(1), Article 102097. doi:10.1016/j.acalib.2019.102097

Osman, M. E. (2020). Global impact of Covid-19 on education systems: The emergency remote teaching at Sultan Qaboos University. Journal of Education for Teaching, 46(4), 463-471. doi:10.1080/02607476.2020.1802583

Osterlind, S. J. (2005). Constructing test items multiple-choice, constructed-response, performance, and other formats. New York, NY: Kluwer Academic Publishers.

Pham, H. T. T., \& Tran, G. T. N. (2019). The revolution in online learning and implication in Vietnamese Universities. HCMCOUJS-Social Sciences, 9(1), 70-77.

Phillips, J. A., Schumacher, C., \& Arif, S. (2016). Time spent, workload, and student and faculty perceptions in a blended learning environment. American Journal of Pharmaceutical Education, 80(6), 102-102. doi:10.5688/ajpe806102

Poon, L. L. M., \& Peiris, M. (2020). Emergence of a novel human coronavirus threatening human health. Nature Medicine, 26(3), 317-319. doi:10.1038/s41591-020-0796-5

Prensky, M. (2001). Digital natives, digital immigrants (Part 1). On the Horizon, 9(5), 1-6. doi:10.1108/10748120110424816

Qian, X., Ren, R., Wang, Y., Guo, Y., Fang, J., Wu, Z. D., ... Members of Steering Committee, Society of Global Health, Chinese Preventive Medicine Association. (2020). Fighting against the common enemy of Covid-19: A practice of building a community with a shared future for mankind. Infectious Diseases of Poverty, 9(1), Article 34. doi:10.1186/s40249020-00650-1

Ribeiro, R. (2020). How university faculty embraced the remote learning shift. Retrieved May 10, 2021, from EdTech Magazine website: https://edtechmagazine.com/higher/article/ 2020/04/ how-university-faculty-embraced-remote-learning-shift 
Sandkuhl, K., \& Lehmann, H. (2017). Digital transformation in higher education - The role of enterprise architectures and portals. In A. Rossmann \& A. Zimmermann, Digital Enterprise Computing (DEC 2017) (pp. 49-60). Böblingen, Germany: Gesellschaft für Informatik.

Shariman, T. P. N. T., Razak, N. A., \& Noor, N. F. M. (2012). Digital literacy competence for academic needs: An analysis of malaysian students in three universities. Procedia - Social and Behavioral Sciences, 69, 1489-1496. doi:10.1016/j.sbspro.2012.12.090

Smedley, J. (2010). Modelling the impact of knowledge management using technology. OR Insight, 23(4), 233-250. doi:10.1057/ori.2010.11

Strielkowski, W. (2020). Covid-19 pandemic and the digital revolution in academia and higher education. In Covid-19 and the 'Digital Revolution' in higher education project (Preprints). doi:10.20944/preprints202004.0290.v1

Tallent-Runnels, M. K., Thomas, J. A., Lan, W. Y., Cooper, S., Ahern, T. C., Shaw, S. M., \& Liu, X. (2006). Teaching courses online: A review of the research. Review of Educational Research, 76(1), 93-135.

Tran, B. X., Nguyen, H. T., Le, H. T., Latkin, C. A., Pham, H. Q., Vu, L. G., ... Ho, R. C. M. (2020). Impact of Covid-19 on economic well-being and quality of life of the Vietnamese during the national social distancing. Frontiers in Psychology, 11(2289), Article 565153. doi:10.3389/fpsyg.2020.565153

Vlachopoulos, D. (2020). Covid-19: Threat or opportunity for online education? Higher Learning Research Communications, 10(1), 16-19. doi:10.18870/hlrc.v10i1.1179

Wagner, N., Hassanein, K., \& Head, M. (2008). Who is responsible for e-learning success in higher education? A stakeholders' analysis. Journal of Educational Technology \& Society, 11(3), 26-36.

Wang, C., \& Zha, Q. (2018). Measuring systemic diversity of Chinese universities: A clusteringmethod approach. Quality \& Quantity, 52(3), 1331-1347. doi:10.1007/s11135-017-0524-5

Wang, C., Cheng, Z., Yue, X. G., \& McAleer, M. (2020). Risk management of Covid-19 by universities in China. Multidisciplinary Digital Publishing Institute, Journal of Risk and Financial Management, 13(2), Article 36. doi:10.3390/jrfm13020036

Wijekumar, K., Ferguson, L., \& Wagoner, D. (2006). Problems with assessment validity and reliability in web-based distance learning environments and solutions. Journal of Educational Multimedia and Hypermedia, 15(2), 199-215.

World Health Organisation (WHO). (2021). Coronavirus disease (COVID-19) pandemic. Retrieved May 27, 2021, from https://www.who.int/emergencies/diseases/novelcoronavirus-2019

Worldometer. (2021). Covid-19 coronavirus pandemic. Retrieved April 10, 2021, from https://www.worldometers.info/coronavirus/\#countries

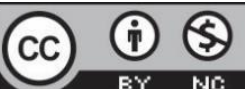

Creative Commons Attribution-NonCommercial 4.0 International License. 